УДК 811.161.2

DOI https://doi.org/10.24919/2308-4863/34-4-21

Ольга РУДЬ, orcid.org/0000-0002-5985-2422

кандидат філологічних наук, дочент,

доиент кафедри української мови і літератури

Сумського державного педагогічного університету імені А. С. Макаренка

(Суми, Україна) olgarud2017@ukr.net

Ірина ГОРБАТЕНКО, orcid.org/0000-0002-6407-6544,

магістрантка факультету іноземної та слов'янської філологї Сумського державного педагогічного університету імені А. С. Макаренка

(Суми, Україна) ira.gorbatenko@ukr.net

\title{
СИМВОЛІКА ОРНІТОЛОГІЧНИХ НАЗВ У ПОЕЗІЇ СЕРГІЯ ЖАДАНА
}

Статтю присвячено вивченню символічної семантики орнітонімів у поетичному мовленні Сергія Жадана. Розглянуто потрактування поняття «символ» у різних галузях науки, визначено його характерні ознаки: філософська смислова наповненість; тяжіння до певного узагальнення, до загальної ідеї; динамічність, рухомість; багатозначність; етнокультурна та контекстуальна зумовленість, зображально-виражальна здатність. У поетичному тексті образ-символ, крім основних значень, успадкованих, генетичних $і$ витворених у просторі національної культури, набуває нових, індивідуально-авторських, які мають вищий ступінь експресивності порівняно з символами, вжитими у традииійному значенні.

Поставлено за мету проаналізувати стильові та функціональні особливості символів орнітологічних назв у поетичних текстах Сергія Жадана. Встановлено, шьо у поезї Сергія Жадана найпоширенішим є слово-символ «птах». Використовуючи традииійну значеннєву основу символу, митець слова надає йому індивідуальноавторського змістового наповнення, суттєво розширює та збагачує значеннєве поле вживаного образу-символу. Виявлено, шьо птахи для Сергія Жадана - ие символ життя, єдності двох світів, символ людської душі, яка спокійно відлітає в інший вимір. У багатьох культурах птах - ие символ волі, безтурботності, безмежного щзастя. В аналізованих поетичних текстах слово-символ «птах» часто містить негативну семантику, символізуючи горе, біду, важке становище людини.

Встановлено, ще образи птахів у поетичних текстах Сергія Жадана часто конкретизовані, названі за видовою належністю: соловей, шпак, голуби, ластівка, півень, чайки, гуси, дрозд, ворона. Аналіз народнопоетичних образів-символів птахів дозволив виокремити індивідуально-авторську символічну семантику орнітонімів. Образи-символи Сергія Жадана містять численні позитивні (соловей-ніжність, мелодійність; ластівка - взаємодопомога, підтримка, посланець Бога; дикі гуси -згуртованість, стійкість, нескореність) і негативні (чайка - прокламачії з сумнівними ілюзіями щастя; шпаки - сварливі родичі) символічні значення.

Ключові слова: символ, орнітологічні назви, символічне значення, семантика, поетична мова.

Olga RUD, orcid.org/0000-0002-5985-2422,

Candidate of Philological Sciences, Associate Professor, Associate Professor at the Ukrainian Language and Literature Department Sumy State Pedagogical University named after A. S. Makarenko (Sumy,Ukraine) olgarud2017@ukr.net

Iryna HORBATENKO, orcid.org/0000-0002-6407-6544

Master's Student at the Faculty of Foreign and Slavic Philology Sumy State Pedagogical University named after A. S. Makarenko (Sumy, Ukraine) ira.gorbatenko@ukr.net

\section{SYMBOLS OF ORNITHOLOGICAL NAMES IN POETRY OF SERGIY ZHADAN}

The article is devoted to the study of symbolic semantics of ornithonyms in poetic speech of Serhiy Zhadan. The interpretation of 'symbol' concept in different branches of science is considered, its characteristic features philosophical semantic content; attraction to a certain generalization, to a general idea; dynamism, mobility; polysemy; 
ethnocultural and contextual conditionality, pictorial and expressive ability are determined. In poetic text, the imagesymbol, in addition to the basic meanings - inherited, genetic, and created in the space of national culture, acquires new - individual-authorial, having a higher degree of expressiveness compared to the symbols used in traditional sense.

The aim is to analyze the stylistic and functional features of the symbols of ornithological names in poetic texts of Sergei Zhadan. It is established that in the poetry of Sergei Zhadan the most common symbol-word is the 'bird'. Using the traditional semantic basis of the symbol, the artist of the word gives it an individual-authorial content, significantly expands and enriches the semantic field of used image-symbol. It was found that birds for Serhiy Zhadan are a symbol of life, unity of two worlds, and the symbol of human soul, which calmly flies away to another world. In many cultures, the bird is a symbol of freedom, serenity, and boundless happiness. In analyzed poetic texts, the word-symbol 'bird'often contains negative semantics, symbolizing grief, misery, the plight of man.

It is established that the images of birds in poetic texts of Serhiy Zhadan are often concretized, named by species: nightingale, starling, pigeons, swallow, rooster, seagulls, geese, blackbirds, crows. The analysis of folk poetic imagessymbols of birds allowed to single out the individual-author's symbolic semantics of ornithonyms. Serhiy Zhadan's symbolic images contain numerous positive (nightingale - tenderness, melody; swallow - mutual aid, support, messenger of God; wild geese - cohesion, resilience, insubordination) and negative (seagull-proclamations with dubious illusions of happiness; starlings - quarrelsome relatives) symbolic values.

Key words: symbol, ornithological names, symbolic meaning, semantics, poetic language.

Постановка проблеми. 3 давніх-давен людину супроводжують символи, за допомогою яких вона намагається передати свої ідеї, зробити їх впізнаваними і зрозумілими. Символи несуть великий обсяг інформації, вони наділені кількома значеннями, оскільки містять ідеї 3 різним смисловим навантаженням (Тресиддер, 1999: 5). При цьому вони залишаються простими і легко запам'ятовуються. Як зазначає В. Кононенко, характерною рисою символу є властивість мотивувати значення не через перенесення, а через фонові значення. Свій зміст ця універсальна категорія виявляє лише в плані встановлення національних, культурних, соціальних, релігійних та інших чинників, які й визначають розуміння символу всіма членами певного соціуму (Кононенко, 1991: 31).

Символіка поетичних текстів Сергія Жадана є фрагментом «символічної картини світу певного етносу, iї художнім відбитком, де символи актуалізують текстовий зміст, формують підтекст вірша, оскільки несуть у собі генетично закодований світогляд» (Панасенко, 2015: 5), вона є елементом індивідуально-авторської мовної картини світу, відображенням світовідчуття поета. Саме тому опис символіки Сергія Жадана є необхідним складником загального дослідження історії національної поетичної мови.

Аналіз досліджень. Різноманітність підходів щодо аналізу символу як універсальної філософсько-естетичної категорії зумовила його вивчення в різних галузях науки: філософії (Г. Гадамер, Е. Кассирер, О. Лосєв, М. Мамардашвілі, Т. Проць, А. П'ятигорський, К. Свасьян), міфології (М. Костомаров, О. Лосєв, Б. Марковський, Е. Мелетинський, У. Тернер), фольклорі (М. Дмитренко, Л. Домилівська, В. Жайворонок, М. Костомаров, М. Максимович, Г. Микитів, О. Потебня, М. Сум- цов), психології (П. Гуревич, Н. Подхватилін, В. Самохвалов, О. Хміляр, К. Юнг,) лінгвістиці (С. Аверинцев, Н. Арутюнова, О. Веселовський, В. Виноградов, С. Срмоленко, В. Калашник, В. Кононенко, Е. Кравченко, О. Потебня, Л. Савченко, Н. Сологуб, Л. Ставицька, Е. Шелестюк), лінгвокультурології (Г. Карпенко, В. Колесов, О. Левченко, В. Маслова, Ю. Мосенкіс, Є. Опаріна, О. Потапенко, Н. Слухай, Ю. Степанов, О. Яницька).

Поетичні символи $є$ предметом лінгвістичних наукових розвідок В. Бережняк, Ю. Бондаренка, С. Єрмоленко, В. Калашника, Н. Левчик, Н. Лисенко, І. Накашидзе, К. Панасенко, Л. Пустовіта, Л. Ставицької, О. Таран. Так, Н. Лисенко у дисертаційному дослідженні «Метафора і символ у поетичному ідіостилі Тодося Осьмачки (Семантика. Стилістика)» виявляє риси символіки поета, особливості індивідуально-авторської реалізації традиційних образів-символів, виробляє класифікацію власне авторських символів Тодося Осьмачки. О. Таран аналізує семантику символів природи в поезії Олександра Олеся, розкриваючи механізм формування у творах поета індивідуально-авторських значень і смислів символів, описує парадигматичні й синтагматичні відношення символів в індивідуальній символічній системі Олександра Олеся.

Питання текстової інтерпретації домінантних мовних символів як невід'ємних складників індивідуального стилю Ю. Іздрика розглядає Ю. Бондаренко, зосереджуючись на словесних символахархетипах. Н. Левчик аналізує дискурс образної символікипоезіїМ.Старицького,приділяючиувагу асоціативним, семантичним, стильовим характеристикам поетичного слова. В. Бережняк окреслює роль поетичних символічних образів у моделюванні мовної картини світу Тараса Шевченка. 
Мета статті - проаналізувати стильові та функціональні особливості символів орнітологічних назв у поетичних текстах Сергія Жадана (на матеріалі збірок поезій «Тамплієри», «Антена», «Список кораблів»).

Виклад основного матеріалу. Для більш повного розуміння поняття «символ» і визначення багатогранності символічної семантики поетичного слова Сергія Жадана вважаємо за доцільне розглянути потрактування цього поняття та визначити його характерні ознаки.

Аналіз довідкової та наукової літератури дав змогу дійти висновку, що більшість визначень поняття «символ» грунтується на образності, умовності та узагальненій сутності символічного явища: символ - «умовне позначення якогось предмета, поняття або явища; художній образ, який умовно відбиває яку-небудь думку, ідею, почуття» (Словник, 1970-1980, т. 9: 174); «тип знака; <...> слово, що має усталені асоціативні зв'язки з відповідним поняттям» (Срмоленко, 2001: 152-153); «складна естетична категорія, вище втілення принципу метафоризації, тобто переносного значення» (Лексикон, 2001: 524); «образ, який виник у результаті метафоризації значення, але входить у соціальну чи особисту сферу» (Мацько, 2003: 308); «умовне позначення якогось предмета, поняття або явища; художній образ, який умовно відбиває яку-небудь думку, ідею, почуття» (Жайворонок, 2006: 537). Зважаючи на неоднозначність потрактування цього поняття, у дослідженні ми спираємося на визначення символу як багатозначного предметного образу, який «об'єднує між собою різні плани художнього відтворення дійсності на основі їх суттєвої спільності, спорідненості; один із поетичних тропів» (Українська мова, 2004: 582).

Науковці окреслюють такі визначальні ознаки символу: філософська смислова наповненість; тяжіння до певного узагальнення, до загальної ідеї; динамічність, рухомість, оскільки він потребує активного сприймання; багатозначність; етнокультурна та контекстуальна зумовленість, зображально-виражальна здатність. Семантика символу досить широка. Крім основних значень, успадкованих, генетичних і витворених у просторі національної культури, в поетичному тексті символ набуває нових, індивідуально-авторських. Як зазначає О. Таран, «індивідуально-авторські смисли художніх символів мають вищий ступінь експресивності порівняно з символами, вжитими в традиційному значенні; у семантиці художніх символів спостерігається поляризація емоційно-оцінного потенціалу лексем-прототипів символів» (Таран, 2002: 5).
Сергій Жадан, використовуючи традиційну значеннєву основу символу, надає йому індивідуально-авторського змістового наповнення, суттєво розширює та збагачує значеннєве поле вживаного образу-символу. У поетичних текстах Сергія Жадана найпоширенішим $є$ слово-символ пmax.

М. Костомаров наголошує на тому, що, вивчаючи символіку птахів, необхідно звертати увагу як на «фізичні їх якості із застосуванням до подібних рис народного характеру», так і на «птаховолхування», яке полягало у спробах дізнатися про своє майбутнє і переслати з ними повідомлення рідним і близьким (Костомаров, 1999: 88).

Згідно 3 багатьма міфами про народження світу саме птахи існували ще до появи суходолу і людей. Міфічний птах як символ творця світу, символ світової душі зображують на дереві життя. Образ птаха постає охоронцем усього живого. У свідомості українського народу птахи здавна асоціювалися 3 людською душею, духом, божим виявом; птахи - це крилаті душі, усе духовне. Вважалося, що душі померлих повертаються весною на землю в образі птахів, а восени повертаються в рай, як і птахи відлітають у вирій.

Для Сергія Жадана птахи - це символ життя, єдності двох світів. Символізм птаха зумовлений їх легкістю і швидкістю пересування, вільним польотом і здатністю досягти небес. У поетичних рядках «Я хочу, щоби птахам легко давався осінній політ, / я хочу, щзоб сонце стояло над кораблями, / щоби птахи відбивались на поверхні озер i боліт, / щоби ти й далі скріплювала собою весь ичей світ» (Жадан, 2018: 25) образ птахів уособлює життя на землі (живе, видиме, тілесне віддзеркалюється у воді) і в той же час є символом людської душі, яка спокійно відлітає в інший світ (осінній політ птахів). Ця символічна семантика птаха підсилюється образом сонця, яке в міфологічному світогляді символізує перемогу життя над смертю, добра над злом, темними силами. Сонячне світло - це символ єдності, впорядкованості світу, яке в поезії поглиблюється словами «...скріплювала ... весь иеей світ».

Причетність птахів до духовного світу, духовних цінностей і моралі розкривається такими рядками: «Птахам простіше: вони взагалі не чули про спасіння душі» (Жадан, 2018: 115), «i птахи голосять, як панотиі до парафії) (Жадан, 2016: 106), «Царство небесне - ие ... надивляються за зорею мудрі птахи» (Жадан, 2020: 10).

$\mathrm{y}$ поетичних текстах Сергія Жадана птахи огорнені загадковістю і мають власний простір: «непорушні кордони держави птахів» (Жадан, 2020: 25), «Птахи малюють вгорі кола свої》 
(Жадан, 2016: 102), «Земля сполоханих риб і степових птахів» (Жадан, 2018: 123), «Птах, що боронить повітряну браму» (Жадан, 2020: 26). Птахи $є$ охоронцями верхнього царства, символами вищого просторового рівня. У міфології тварини розподіляються відповідно до давніх уявлень про тричленну структуру світового простору. 3 верхнім рівнем (світом небес) асоціюються образи птахів, із середнім (земним простором) копитні тварини, із нижнім рівнем (підземним світом) - жаби, гади, миші, риби і деякі інші тварини (Тресиддер, 1999: 11).

У багатьох культурах птах - це символ волі, безтурботності, великого щастя: щаслива людина порівнюється з птахом, який високо літає. У поетичних текстах Сергія Жадана вільному польотові птаха протиставлено горе, біду, важке становище людини: «Будуть птахи без утіхи й прихистку / битися між деревами сірими. / Будуть псувати святкову статистику / вдови і сироти» (Жадан, 2020: 93). Символічна семантика лексеми птахи підсилюється введенням у контекст образу сірих дерев як символу безвиході, безнадії й відчаю.

Особливої символічної семантики образу птаха надають оригінальні індивідуально-авторські порівняння: «змучений птаx, ніби гачок, чіпляється за вітряний потік» (Жадан, 2018: 243), «і голос зривається, ніби птах, / цио замерз на льоту» (Жадан, 2016: 72). У поетичних рядках Сергія Жадана птах символізує приреченість долі, метафорично - беззахисність людини перед жорстокими реаліями сьогодення.

Образи птахів у поетичних текстах Сергія Жадана конкретизовані, тобто названі за видовою належністю. Найчастіше зустрічаються образи таких птахів: соловей, шпак, голуби, ластівка, півень, чайки, гуси, дрозд, ворона. Так, символізм орнітоніма соловей побудований на красі співу птаха навесні в шлюбний період. Здавна народ вірив, що високий і чистий спів птаха здатний очистити душу людини, піднести іiї і втішити. В уявленні українського народу соловей - це символ кохання, радості і ніжності, а також неповторної майстерності співака. У поетичних рядках Сергія Жадана «I він слухає, як прописуються $i$ звучать / голосними літерами / в тексті темряви /ластівки $i$ солов $\boldsymbol{\imath}\rangle$ (Жадан, 2020: 116) реалізується символічна семантика ніжності, мелодійності. У давньогрецькій міфології соловей вважався оракулом у справах кохання, йому довіряли найпотаємніше.

Лексема «соловей» стоїть в одній семантичній площині з лексемою «ластівки». Ці два птахи символізують початок, зародження життя, надію на відновлення і розквіт як природи, так і людської душі: «Саме те, щзо було на початку. Саме те, заради чого здіймаються / в небо ластівки. / Доки твориться світ, / виснуть над деревами, мов гріхи над душею» (Жадан, 2020: 23); «Ластівки скріплюють глиною розламаний час» (Жадан, 2018: 289).

У християнській міфології ластівка - це улюблена Божа пташка, яка своїм щебетанням прославляє Всевишнього, наче молитвою. Українці вірили: там, де ластівка звила гніздо, буде щаслива родина, пануватиме добро і злагода. Розорити іiі гніздо - великий гріх. Ластівка - це символ щасливого родинного життя, любові, ласки і ніжності. Сергій Жадан у своїх поетичних творах розвиває народну символічну семантику орнітоніма, розширює їі. Ластівка для нього - це символ взаємодопомоги, підтримки, всепереможної любові: «Серие найменшої ластівки сильніше за туман» (Жадан, 2020: 26). Ця семантика акцентована рядками «душа найбезнадійнішої птахи / варта нашого хвилювання» (Жадан, 2020: 26), де птаха нещаслива, згорьована людина, яка зазнала біди.

Символіка поезії Сергія Жадана особлива, вона вимагає глибокого прочитання поетичного тексту, заглиблення в семантику кожного слова. Символічне значення часто розкривається, стає впізнаваним і зрозумілим у широкому контексті. Словосимвол ластівка слугує символом посланця Бога на землі, який дає кожній людині в рівній мірі добро, щастя, любов і посилає певні випробування: «Ластівки, ніби кравецькі ножиці, / вперто розпорюють червневе повітря / Ділять натруджено день по дневі, / ділять його - порівну кожному» (Жадан, 2018: 172). Образ ножиць є натяком на «гостроту», жорстокість світу, в якому живе людина. Символічна семантика орнітоніма ластівка увиразнюється рядками «<... dicmaнеться рівно стільки, / скільки відпущено, скільки відміряно» (Жадан, 2018: 173). На переконання віруючих, життя людини - в руках Господа Бога, і тільки від нього залежить, яке воно буде - щасливе чи нещасливе, кому скільки відміряно прожити і коли призначено померти.

Символіка диких гусей багато в чому співпадає з символікою лебедя, вони часто взаємозамінюються, ототожнюються. У народному уявленні дикі гуси-лебеді $є$ провісниками весни, вони символізують повернення до витоків, до рідного дому. Негативну конотацію гуси-лебеді реалізують у народних казках («Івасик-Телесик», «Гусилебеді»), в яких ціптахи виступають перевізниками між двома світами, темними і добрими силами.

Якщо лебідь вербалізує позитивну семантику (любов, подружня вірність, щаслива родина), то слово-символ гуси в українській народній фра- 
зеології вживається 3 негативною семантикою і слугує символом брехливої людини, пліткарки («гусей пускати»), неохайної, неакуратної господині («наче гуси ночували»).

У поезії Сергія Жадана образ диких гусей символізує згуртованість, стійкість, нескореність перед бідою: «Але годі нарікати, - говорять одне до одного / дикі гуси на зимовому березі, - тримаймося купи, / гріймося нашою гусячою вірою» (Жадан, 2018: 279). Ця символічна семантика простежується і в наступному тексті: «Знаєш, щุо буде иієї весни: / диких гусей залізні ключі / сядуть в долинах Псла і Десни» (Жадан, 2018: 243), що підсилюється в широкому контексті виразами «залізні ключі», «твердість трунтових вод».

В українській символіці півень є символом вогню, вранішньої пори, світла і сонця. За народними віруваннями крик півня віщує наближення дня, відганяє від хати злих духів. У давнину в новозбудовану хату першим заносили півня, який здатний захистити від «нечистої сили».

У поетичних рядках Сергія Жадана орнітонім півень наповнений неоднозначною символічною семантикою: «Сонце, мов півень із відрубаною головою, б'є крильми. / Вітає ией дивний світ, найсправедливіший зі світів» (Жадан, 2018: 13). Півень символізує зародження дня, пробудження природи, жертовність заради нового життя. Підтекст цього образу торкається підсвідомості, апелює до сугестивного сприймання віршорядків, бо маємо контекстний оксиморон: поєднання сонця (символу життя) і півня із відрубаною головою (негативна семантика закінчення існування), що простежуємо і в рядках «Перекупки несуть на заріз червоних півнів у чорних мішках» (Жадан, 2020: 10).

За легендою чайка - це згорьована жінка, яка після смерті свого чоловіка стала чайкою. В українській народнопоетичній творчості чайка символізує матір-вдову, яка побивається за дітьми-сиротами, гірко плаче-квилить за їхньою нещасливою і важкою долею. У Сергія Жадана цей птах асоціюється із певними прокламаціями, часто нікому не потрібними, з сумнівними ілюзіями щастя: «Чайки - розкидані, мов листівки, / в яких так багато всього намріяно» (Жадан, 2018: 173).
За народними віруваннями птахи мають контакт із божественними сферами, доставляють звідти послання. Шамани прикрашали свій одяг пір'ям, надівали пташині маски, прагнучи «долетіти» зїх допомогою до вищих рівнів знання. Птахи вважалися втіленням мудрості, інтелекту і блискавичної думки (Тресиддер, 1999: 357). Ця символічна семантика простежується і в поезії Сергія Жадана: «Але завіса світу - така пурпурова, / осипається в ріки вигорілими зірками, / $і$ иі сигнали іï-мов арамейська мова: / ї̈ розуміють хіба що ластікки зі шпаками» (Жадан, 2020: 7), де орнітоніми ластівки і шпаки символізують знання, розуміння знаків природи, мудрість, життєвий досвід.

В усній народній творчості шпак - це провісник весни, початок нового життя, молодості. Характерна особливість цих птахів - збиратися у великі зграї, наслідувати голоси інших птахів та імітувати різні звуки зумовлює виникнення індивідуально-авторського символічного значення «велика сварлива родина»: «Чорні шпаки, як сварливі родини, / з відчаєм обсідають черешні〉 (Жадан, 2020: 142). У широкому контексті в образі чорних шпаків уособлено долю хасидів, які щороку повертаються в місця зародження їхнього духовного вчення і не завжди знаходять порозуміння з місцевими жителями.

Висновки. Аналіз дефініції поняття «символ» дозволив виявити відсутність такого тлумачення, яке б повністю враховувало визначальні ознаки і специфічну роль символу. Лінгвістичні дослідження засвідчили, що символу відводиться особливе місце в поетичному тексті, який формує підтекст і $є$ дієвим засобом вираження авторського задуму, світогляду та світосприйняття.

Сергій Жадан використовує у своїй поезії як традиційні образи-символи птахів, які доповнюються новими відтінками значень, так і витворює власне авторські символічні значення орнітонімів, що увиразнюють індивідуальність творчої манери митця. Його образи-символи птахів поєднують небесний і земний світи, сакральне й повсякденне, містять численні позитивні (вісники весни, нового життя; кохання, родинний затишок; знання, мудрість) і негативні (зло, нещастя, приреченість життя, важка доля) символічні значення.

\section{СПИСОК ВИКОРИСТАНИХ ДЖЕРЕЛ}

1. Венжинович Н. Про компонент-символ у мовних одиницях. Науковий вісник Ужгородського університету. Серія: Філологія. Випуск 1 (41). Ужгород, 2019. С. 38-46.

2. Єрмоленко С. Я., Бибик С. П., Тодор О. Г. Українська мова, короткий тлумачний словник лінгвістичних термінів / за ред. С. Я. Єрмоленко. Київ : Либідь, 2001. 224 с.

3. Жадан С. Антена [Текст]: поезії. Чернівці : Меридіан Черновіц, 2018. 304 с.

4. Жадан С. Список кораблів [Текст]. Чернівці : Меридіан Черновіц, 2020. 160 с.

5. Жадан С. Тамплієри. Поезії. Чернівці : Книги - XXI; Meridian Czernowitz, 2016. 120 c. 
6. Жайворонок В. В. Знаки української етнокультури : словник-довідник. Київ : Довіра, 2006. 703 с.

7. Кононенко В. І. Словесні символи в семантичній структурі фраземи. Мовознавство, 1991. № 1. С. 30-36.

8. Костомаров М. І. Слов'янська міфологія: вибрані праці з фольклористики й літературознавства. Київ : Либідь, 1994. $382 \mathrm{c}$

9. Лексикон загального та порівняльного літературознавства / за ред. А. Волкова. Чернівці : Золоті литаври, 2001. $636 \mathrm{c}$.

10. Мацько Л. І., Сидоренко О. М., Мацько О. М. Стилістика української мови : підручник / за ред. Л. І. Мацько. Київ : Вища школа, 2003. 462 с.

11. Панасенко К. О. Символіка поетичного тексту як об' єкт перекладу (на матеріалі українських і російських перекладів англомовної поезії XIX - XX ст.) : дис. канд. філол. наук: 10.02.16 - Перекладознавство. Херсон, 2015. 247 с.

12. Словник української мови: в 11 тт. / АН УРСР. Інститут мовознавства; за ред. І. К. Білодіда. Київ : Наукова думка, 1970-1980. Т. 9. С. 174.

13. Таран О. С. Семантика символів природи в поезіях Олександра Олеся: лінгвопоетичний та етнокультурний аспекти : автореферат канд. філол. наук. Харків, 2002. 19 с.

14. Тресиддер Дж. Словарь символов / Пер. с англ. С. Палько. Москва : ФАИР-ПРЕСС, 1999. 448 с.

15. Українська мова. Енциклопедія / Редкол.: Русанівський В. М. (співголова), Тараненко О. О. (співголова), М. П. Зяблюк та ін. 2ге вид., випр. і доп. Київ : Видво «Укр. енцикл.» ім. М. П. Бажана, 2004. 824 с.

\section{REFERENCES}

1. Venzhynovych N. Pro komponent-symvol u movnykh odynytsiakh [On the component-symbol in language units]. Scientific Bulletin of Uzhhorod University. Series: Philology. Issue 1 (41). Uzhhorod, 2019. 38-46 p. [in Ukrainian].

2. Yermolenko S. Ya., Bybyk S. P., Todor O. H. Ukrainska mova, korotkyi tlumachnyi slovnyk linhvistychnykh terminiv [Ukrainian language, short explanatory dictionary of linguistic terms] / Ed. S. Ya. Yermolenko. Kyiv : Lybid, 2001. 224 p. [in Ukrainian].

3. Zhadan S. Antena [Text]: poezii [Antenna [Text]: poetry. Chernivtsi : Merydian Chernovits, 2018. 304 p. [in Ukrainian].

4. Zhadan S. Spysok korabliv [Text] [List of ships [Text]. Chernivtsi : Merydian Chernovits, 2020. 160 p. [in Ukrainian].

5. Zhadan S. Tampliiery. Poezii [Templars. Poetry]. Chernivtsi : Knyhy - XXI; Meridian Czernowitz, 2016.120 p. [in Ukrainian].

6. Zhaivoronok V. V. Znaky ukrainskoi etnokultury : Slovnyk-dovidnyk [Signs of Ukrainian ethnoculture : Dictionary-reference]. Kyiv : Dovira, 2006. 703 p. [in Ukrainian].

7. Kononenko V. I. Slovesni symvoly v semantychnii strukturi frazem [Verbal symbols in the semantic structure of an idiom]. Linguistics, 1991. № 1. P. 30-36 [in Ukrainian].

8. Kostomarov M. I. Slovianska mifolohiia : vybrani pratsi z folklorystyky i literaturoznavstva [Slavic mythology: selected works on folklore and literary studies]. Kyiv : Lybid, 1994. 382 p. [in Ukrainian].

9. Leksykon zahalnoho ta porivnialnoho literaturoznavstva [Lexicon of general literature studies and comparativism] Ed. A. Volkova. Chernivtsi : Zoloti lytavry, 2001. 636 p. [in Ukrainian].

10. Matsko L. I., Sydorenko O. M., Matsko O. M. Stylistyka ukrainskoi movy : pidruchnyk [Stylistics of the Ukrainian language : textbook]/ Ed.

L. I. Matsko. Kyiv : Vyshcha shkola, 2003. 462 p. [in Ukrainian].

11. Panasenko K. O. Symvolika poetychnoho tekstu iak obiekt perekladu (na materiali ukrainskykh ta rosiiskykh perekladiv anhlomovnoi poezii XIX - XX st.) : dys. kand. filol. nauk: 10.02.16 - Perekladoznavstvo [Symbolism of poetic text as a translation object (based on the material of Ukrainian and Russian translations of English poetry of the XIX-th - XX-th centuries): thesis for a Candidate Degree of Philological Sciences: 10.02.16 - translation studies]. Kherson, 2015.247 p. [in Ukrainian].

12. Slovnyk ukrainskoi movy: v $11 \mathrm{tt}$. [Dictionary of the Ukrainian language: in 11 vols.] / [USSR Academy of Sciences. Institute of Linguistics; Ed. I. K. Bilodid. Kyiv : Naukova dumka, 1970-1980. T. 9. P. 174 [in Ukrainian].

13. Taran O. S. Semantyka symvoliv pryrody v poesiiakh Oleksandra Olesia: linhvopoetychnyi ta etnokulturnyi aspekty : avtoreferat kand. filol. nauk [Semantics of nature symbols in poems of Alexander Oles: linguopoetic and ethnocultural aspects: abstract of thesis for a Candidate Degree of Philological Sciences]. Kharkiv, 2002. 19 p. [in Ukrainian].

14. Tresyder Dzh. Slovar symvolov [Dictionary of Symbols] / [translation from English S. Palko]. Moscow : FAIR-PRESS, 1999. 448 p. [in Russian].

15. Ukrainska mova. Entsyklopediia [Ukrainian language. Encyclopedia] / Editors: Rusanivsky V. M. (co-chairman), Taranenko O. O. (co-chairman), M. P. Zyablyuk and others. 2 end ed., revised and extended. Kyiv : Mykola Bazhan All-Ukrainian State Specialized Publisher "Ukrainian Encyclopedia", 2004. 824 p. [in Ukrainian]. 